\title{
提供情報及び個人特性の差異がもたらす 飲料水リスク認知への影響
}

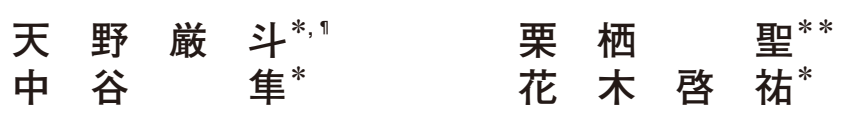

\section{Effect of Provided Information and Recipient's Personality on Risk Perception of Drinking Water}

\author{
Iwato AMANO*, , Kiyo KURISU**, \\ Jun NAKATANI* and Keisuke HANAKI*
}

* Department of Urban Engineering, The University of Tokyo, 7-3-1 Hongo, Bunkyo-ku, Tokyo 113-8656, Japan

** Research Center for Advanced Science and Technology, The University of Tokyo, 4-6-1 Komaba, Meguro-ku, Tokyo 153-8904, Japan

\begin{abstract}
The effect of information provision on the risk perception of drinking water was investigated on the basis of information contents and the respondent's personality and socio-demographics. The respondents were divided into 11 groups and the combination of provided information was varied for each group. The effectiveness of information provision was observed as a decrease in the "unknown" score, while the "dread" score was increased in all the groups with information provision. Numerical information like the number of group infections and DALY itself showed no marked effect on risk perception; however, the recognition of the number of group infections showed an effect on risk perception. Larger risk perceptions and a larger effect of information provision were observed in the respondents who have personality traits like "recklessness" and willingness to actively accept risks.
\end{abstract}

Keywords: Tap water; Bottled water; DALY; Information provision; Risk communication

\section{1.はじめに}

分析技術の発達により新たな物質が発見されるなどし て,リスクコミュニケーションが必要とされる場面は 増加していると考えられる ${ }^{1,2)}$ 。飲料水も例外ではなく, 例えば近年では水道水やボトル水中のウイルスゲノム の存在可能性が指摘されているが3 5), このような事例 では，専門家と一般市民とのリスク認知に乘離が生じて いると考えられ，それを埋めるための効果的なコミュニ ケーションが求められる。

リスクコミュニケーションにおいては, 社会全体とし てリスクを回避するとともに，市民各個人の不安を解消 することも大きな目的のひとつとなっている。これまで, リスクに対し人々がどのような認知構造を持つかを明ら かにする研究が行われてきており ${ }^{6)}$, その中でも情報伝 達法は重要な検討課題となっている。

表現法によるコミュニケーション効果の違いについて は, 人型による表現の有効性や, 比較対象の提示の有 効性などが示されてきている7)。さらに, Gigerenzer and Hoffrage $^{8)}$ は数值情報を提供する場合には, 確率で示す
よりも頻度形式の方が受け手に理解されやすく，バイア スを減少させる表現であることを明らかにしている。

また，情報を受け取った人々の認知を一定の方向に変 容させるための情報伝達技法として, 説得的コミュニ ケーションの有効性が示されている ${ }^{9)}$ 。説得の技法は主 に恐怖喚起コミュニケーションと一面的/両面的コミュ ニケーションの二つからなるとされている。身体への危 険を伝えて, 恐怖を引き起こす内容を伝えるのが恐怖 喚起コミュニケーションであり, 誘導しようとする立場 に関する賛成論だけを伝えるのが一面的, 反対論もあわ せて伝えるのが両面的コミュニケーションである。木 下ら ${ }^{10.11)}$ は放射線を利用した科学技術に関して両面的コ ミュニケーションを用いたリスクコミュニケーションを 試み, リスク認知は変化しないが, 情報の送り手や内容 に対する信頼は高くなるという結論を得ている。

水道水においても, 平山らがリスク認知構造モデルを 構築しており,リスク認知の構成要素における「情報量」

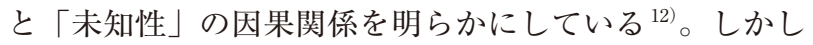
ながら, 水道水を含めた飲料水のリスク認知に対する情 報の影響はいまだ研究途上であり，十分に明らかにされ

\footnotetext{
* 東京大学大学院工学系研究科都市工学専攻 ₹ 113-8656 東京都文京区本郷 7-3-1

** 東京大学先端科学技術研究センター † 153-8904 東京都目黒区駒場 4-6-1

凤 連絡先 : amano@env.t.u-tokyo.ac.jp, iwato.a@gmail.com
} 
ていない。

さらに, リスク認知に影響を与える要因として，その人 の社会的態度などの内部要因や, 性別, 居住地域などの 個人属性も考えられる ${ }^{13)}$ 。そのため, 各個人の差異を踏 まえた提供情報のリスク認知への影響評価が必要である。

そこで, 本研究では, 飲料水に対する人々のリスク認 知を対象とし, 以下の 4 つの論点を設定し, 各個人の差 異や，情報を提供することがその内容や示し方によって どのような影響を与えるかを明らかにすることを研究目 的とした。

1）情報提供によって人々のリスク認知はどのよう に変化するか

2）一面的情報提供と両面的情報提供による違いは 見られるか

3）数值情報の示し方によって，リスク認知はどのよ うに変化するか

4）個人のリスクに対する感じ方（個人特性）や個人 属性によるリスク認知の違いは見られるか

リスク認知に作用する因子としては, 一般に重要とさ れ，水道水に関しても抽出されている ${ }^{12}$ 恐ろしさ因子と 未知性因子 ${ }^{6}$ を取り上げることとした。水道水, 浄水器を 通した水, ボトル水を対象とし, アンケート調査票によっ て情報を提供すると共にリスク認知を問うことにより，提 供情報とリスク認知の関連性を評価するものとした。

\section{2. 調査及び研究手法}

\section{1 調査票の設計}

調査票は, 大きく分けて (1)現状飲料水認識, (2)情報 提供, (3) リスク認知, (4)個人特性, (5)個人属性の 5 つに より構成した。

\subsection{1 現状飲料水認識}

第一に，現在の飲料水の利用状況と味への認識をたず ねた。水道水（そのまま）, 浄水器を通した水（以下， 浄水器), ボトル水, ウォーターサーバーの水 (以下, サー バー）の 4 種類に対して, それぞれ飲む頻度と, どの程 度おいしいと思うかを 4 件法（よく飲む〜ほとんど飲ま ない，思う〜思わない）により問うた。「ほとんど飲ま ない」と答えた飲料水に対しては, 味への認識は問わな かった。

\section{1.2 情報提供}

情報提供では, 飲料水 (水道水, 浄水器, ボトル水) のリスクに関する情報をグループごとに異なる組み合わ せにて提供した。提供情報の内容によってグループは 11 に分けた。提供情報は, 水道水に関する $(\mathrm{a})$ 基礎情報, （b）ネガティブ情報，(c)感染事例，(d) DALY（DisabilityAdjusted Life Years, 障害調整生命年), 浄水器に関する (e)ネガティブ情報，(f)ポジティブ情報，ボトル水に関す
る $(\mathrm{g})$ ネガティブ情報, (h)ポジティブ情報から構成した (Table 1)。G1 〜 3 と G7 〜 10 には水道水の情報のみ を, G4〜6 は水道水, 浄水器, ボトル水の情報を与え た。G7〜10 はDALY の示し方をそれぞれ変えた。G11 は情報を提供しない群とした。G1，4 は一面的, その他 の情報提供グループはポジティブ及びネガティブ双方の 情報を提供する両面的コミュニケーションを意四したも のである。以下, 各提供情報の内容について詳説する。

水道水の $(\mathrm{a})$ 基礎情報としては, 水度水のリスクをもた らすものとして, クリプトスポリジウムや細菌, ウイルス といった病原微生物と, トリハロメタン等の発がん性消毒 副生成物が存在することをまず述べた ${ }^{14)}$ 。その上で，水 道水質は水道水質基準によって厳しく管理されているこ と, 塩素が消毒剤として極めて効果的であることを記述し た ${ }^{14)}$ 。水道水の(b)ネガティブ情報としては, 一方で塩素 はクリプトスポリジウム等の原虫類には十分な消毒効果を 示せないこと, また, 残留塩素がウイルスにはあまり効果 がないといった実験結果も示されていることを述べた ${ }^{14)}$ 。

浄水器の $(\mathrm{e})$ ネガティブ情報としては, 残留塩素の除去 により殺菌力が低下し, 微生物が繁殖する可能性がある こと ${ }^{15)}$ ，また，カートリッジから人体に有害な化学物質 が溶出しているという研究があること ${ }^{16)}$, さらに, カー トリッジを交換しないことにより浄水器内に微生物が 繁殖する可能性があること ${ }^{15)}$ を述べた。浄水器の(f)ポジ ティブ情報としては, 浄水器は国家規格で定められた試 験方法による性能表示がされていること，また，クリプ トスポリジウムやトリハロメタンを除去する性能がある こと ${ }^{17)}$ を述べた。

ボトル水の $(\mathrm{g})$ 辛ガティブ情報としては, ボトル水は水 道水よりも緩い基準で販売されていること ${ }^{18)}$ ，また，ノ ロウイルスの遺伝子配列が検出されたという研究があ ること ${ }^{3,5)}$, さらに, 唾液や手指による污染により細菌 が増殖する可能性があること㬏を述べた。ボトル水の(h) ポジティブ情報としては, ノロウイルスの遺伝子配列は 検出できなかったという調查結果 ${ }^{4,5}$ があること，また， 経験的に人体に対して安全であること 20)を述べた。

これらの情報はいずれも 150 ～ 200 字程度で簡潔に示 し, さらに, 各提供情報の後に簡単な質問を設け, 回答 者が読み飛ばすことがないよう工夫した。

さらに, 数值情報の影響をみるために, 水道水の感染 事例や DALY の情報 ${ }^{21,22)}$ (Table 2) も提供した。水道水 の(c)感染事例としては, 日本での水道水による集団感染 事例として，1980 年代から 1996 年までクリプトスポリ ジウムによるもので 2 件, 細菌によるもので少なくとも 84 件, ウイルスによるもので 1 件発生していることを 述べた。(d) DALY については, Table 2 の左側に示した ような説明を加えた上で, G7 は数值, G8 は秒数, G9

Table 1 各グループへの提供情報（○が情報を与えたことを示す）

\begin{tabular}{|c|c|c|c|c|c|c|c|c|c|c|c|c|}
\hline \multirow{2}{*}{ 対象 } & \multirow{2}{*}{ 提供情報 } & \multicolumn{11}{|c|}{ Group 番号 } \\
\hline & & 1 & 2 & 3 & 4 & 5 & 6 & 7 & 8 & 9 & 10 & 11 \\
\hline 水道水 & $\begin{array}{l}\text { (a) 基礎情報 } \\
\text { (b) ネガティブ } \\
\text { (c) 感染事例 } \\
\text { (d) DALY }\end{array}$ & $\mathrm{O}$ & $\begin{array}{l}0 \\
0\end{array}$ & $\begin{array}{l}0 \\
0 \\
0\end{array}$ & $\bigcirc$ & $\begin{array}{l}0 \\
0\end{array}$ & $\begin{array}{l}0 \\
0 \\
0\end{array}$ & $\begin{array}{l}0 \\
0 \\
0 \\
0\end{array}$ & $\begin{array}{l}0 \\
0 \\
0 \\
0\end{array}$ & $\begin{array}{l}\bigcirc \\
0 \\
0 \\
0\end{array}$ & $\begin{array}{l}\bigcirc \\
\bigcirc \\
0 \\
0\end{array}$ & \\
\hline $\begin{array}{l}\text { 浄水器 } \\
\text { ボトル水 }\end{array}$ & $\begin{array}{l}(\mathrm{e}, \mathrm{g}) \text { ネガティブ } \\
(\mathrm{f}, \mathrm{h}) \text { ポジティブ }\end{array}$ & & & & $\mathrm{O}$ & $\begin{array}{l}\bigcirc \\
0\end{array}$ & $\begin{array}{l}\bigcirc \\
0\end{array}$ & & & & & \\
\hline
\end{tabular}


Table 2 DALYの示し方

\begin{tabular}{|c|c|c|c|c|c|}
\hline \multirow{6}{*}{ 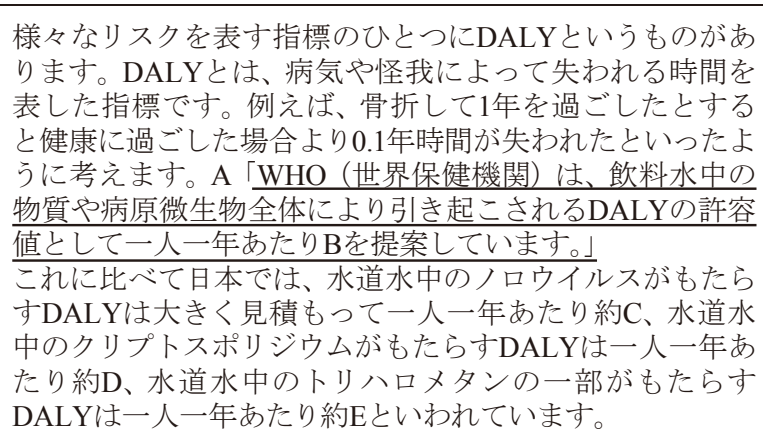 } & & G7 & G8 & G9 & G10 \\
\hline & A & 示す & 示す & 示す & 示さない \\
\hline & $\mathrm{B}$ & $1.0 \times 10^{-6}$ 年 & 約 30 秒 & $10^{-6}$ 年 & - \\
\hline & $\mathrm{C}$ & $1.0 \times 10^{-6}$ 年 & 30 秒 & ほぼ同じくらい & $1.0 \times 10^{-6}$ 年 \\
\hline & $\mathrm{D}$ & $0.6 \times 10^{-6}$ 年 & 20 秒 & 6割 & $0.6 \times 10^{-6}$ 年 \\
\hline & $\mathrm{E}$ & $0.1 \times 10^{-6}$ 年 & 3 秒 & 1割 & $0.1 \times 10^{-6}$ 年 \\
\hline
\end{tabular}

Table 3 リスク認知に関する因子分析結果

\begin{tabular}{|c|c|c|c|c|c|c|c|}
\hline \multicolumn{2}{|r|}{ 質問文* } & \multicolumn{2}{|c|}{ 水道水 } & \multicolumn{2}{|c|}{ 浄水器 } & \multicolumn{2}{|c|}{ ボトル水 } \\
\hline & & $\mathrm{f} 1$ & $\mathrm{f} 2$ & f1 & $\mathrm{f} 2$ & f1 & $\mathrm{f} 2$ \\
\hline $\mathrm{S} 1$ & $\begin{array}{l}\text { XX を飲むことによって大規模な感染症が } \\
\text { 発生することもあると思う }\end{array}$ & .970 & .198 & .792 & .009 & 1.061 & .290 \\
\hline $\mathrm{S} 2$ & $\begin{array}{l}\text { XX を飲むことによって命にかかわるような } \\
\text { 健康影響が起きることもあると思う }\end{array}$ & .919 & .105 & .852 & -.003 & 1.076 & .217 \\
\hline $\mathrm{S} 3$ & $\begin{array}{l}\text { XX を飲むことにより } \\
\text { 下痢症になる可能性が高まると思う }\end{array}$ & .700 & -.108 & .850 & -.014 & .722 & -.148 \\
\hline S4 & $\begin{array}{l}\text { XXを飲むことにより } \\
\text { 発ガンの可能性が高まると思う }\end{array}$ & .656 & -.146 & .860 & -.015 & .734 & -.171 \\
\hline S5 & XX を飲むことは直感的に恐ろしいと思う & .627 & -.127 & .757 & -.025 & .606 & -.205 \\
\hline S6 & $\begin{array}{l}\text { XX を飲むことによる } \\
\text { 健康リスクを小さくするのは難しいと思う }\end{array}$ & .400 & -.358 & .718 & .031 & .485 & -.290 \\
\hline S7 & $\begin{array}{l}\text { XX を飲むことによって健康にどのような } \\
\text { 影響があるかよくわからないと思う }\end{array}$ & .341 & -.067 & .459 & .148 & .418 & -.046 \\
\hline S8 & $\begin{array}{l}\text { XX を飲むことによる健康リスクは } \\
\text { 過去に比べて増大していると思う }\end{array}$ & .103 & -.735 & .783 & -.050 & .347 & -.571 \\
\hline S9 & $\begin{array}{l}\text { XX を飲むことによる } \\
\text { 健康リスクはすぐに発生すると思う }\end{array}$ & -.205 & .585 & -.736 & .100 & -.309 & .595 \\
\hline $\mathrm{S} 10$ & $\begin{array}{l}\text { あなたの周りの人々はXX を飲むことによる } \\
\text { 健康影響について正確な知識を持っていると思う }\end{array}$ & .110 & .302 & .099 & 1.024 & .171 & .450 \\
\hline S11 & $\begin{array}{l}\text { XX を飲むことによる健康影響は } \\
\text { 科学的に解明されていると思う }\end{array}$ & -.045 & .229 & -.113 & .380 & .045 & .336 \\
\hline & 説明された分散の割合 & $47 \%$ & $11 \%$ & $53 \%$ & $12 \%$ & $55 \%$ & $12 \%$ \\
\hline
\end{tabular}

* XXの部分には, 水道水, 浄水器を通した水, ボトル水がそれぞれ入る。

は基準值との比率で示し， G10 は WHO の基準を示さず に数値のみ示した。

これらの情報提供の後，与えられた情報への信頼を 4 件法（信頼できる〜信頼できない）で問い，その理由に ついても尋ねた。

\subsection{3 リスク認知}

次に，「恐ろしさ因子」と「未知性因子」 ${ }^{6)}$ の抽出を想 定した飲料水のリスク認知に関する質問を水道水, 浄水 器，ボトル水についてそれぞれ行った。

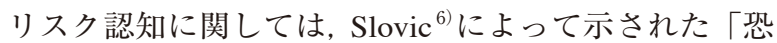
ろしさ因子 (Dread factor)」と「未知性因子 (Unknown factor）」の 2 つ因子が安定して抽出できることが知ら れており，本研究でもこの 2 つ因子を利用した。

Slovic が示している「恐ろしさ因子」に影響す る要素としては, 直感的に恐ろしい (Dread), 無 意識 (Involuntary), 個人でコントロールできない (Uncontrollable), 被害が不公平 (Not equiTable), 災害の 範囲が広い（Global catastrophic），一度に多くの被害 者が出る (Catastrophic)，簡単に減らすことができな
い(Not easily reduced), リスクが増大している（Risk increasing), 死につながる (Consequences Fatal), 将来世 代への影響がある（High risk to future generations）といっ たものが挙げられている。一方,「未知性因子」として は, 影響がすぐあらわれない (Effect delayed), 進行過 程が見えにくい (Not observable), よく知られていない (Unknown to those exposed), 新しい (New risk), 科学的 に解明されていない（Risks unknown to science）といっ た要素が影響するとされている。

本研究では, これらの要素を考慮して質問文を作成し, 4 件法（そう思う〜そう思わない）で問うた。個々の質 問文については結果に扔ける Table 3 に示してある。さ らに, 情報提供に伴う飲料水選択への影響をみるため, 水道水, 浄水器, ボトル水のうち今後いずれを飲みたい か問うた。

\section{1.4 個人特性}

さらに，個人の特性を調べるため, リスク受容性 ${ }^{23)}$ と リスク回避志向性 ${ }^{13)}$ の抽出を目的とした質問を行った。 リスク認知に影響を与える要因としては, 発生源の特 
徵や災害の特質などの外部要因以外にも，その人の社会 的態度などの内部要因が考えられる ${ }^{13)}$ 。本研究ではその 内部要因として，2つの尺度を取りあげる。

「リスク受容尺度（Scale of Risk Acceptance: SRA）」は 木下ら ${ }^{23)}$ によって示された尺度であり, 内部要因の一つ として, リスク対象に対する対応の潜在的性向ないし構 えを測定したものである。

一方，楠見 ${ }^{13)}$ は日常におけるリスクに対する傾向性を
明らかにするために，リスク回避志向とリスク志向の両 者を含めた質問を行っている。

本研究では, 両尺度で共通に問うている「慎重に行動 する」という項目をひとつにまとめた。さらに, リスク 回避志向性尺度については, 飲料水のリスク認知と関連 が予想される要素として，「健康には気をつけて生活を している」と，「夕バコは身体に悪いので吸わないよう にしている」という質問文を独自に加えた。質問は 4 件

Table 4 SRA に関する因子分析解析結果

\begin{tabular}{|c|c|c|c|c|c|}
\hline 質問文 & $\mathrm{fl}$ & $\mathrm{f} 2$ & $\mathrm{f} 3$ & f4 & f5 \\
\hline 何事にも用心深く対応する & .811 & .005 & -.021 & .023 & .000 \\
\hline 失敗しないように何事も慎重に物事を進める & .793 & -.019 & .010 & -.011 & -.034 \\
\hline 難しい問題は全体を見通してからでないと始めない & .674 & .017 & .004 & -.002 & .038 \\
\hline 自分の力量を考えずに冒険してしまう & -.014 & .769 & -.032 & .046 & -.009 \\
\hline 冒険できそうなことがあると、気づいたときには始めている & .027 & .744 & .101 & -.014 & .000 \\
\hline 向こう見ずだと人に言われることがある & -.007 & .742 & -.045 & -.003 & .020 \\
\hline 新しいことにチャレンジするのが好きである & -.079 & .028 & .800 & .033 & -.019 \\
\hline 困難な問題ほどやりがいがある & .050 & .028 & .719 & -.049 & .014 \\
\hline うまくいかなくても最後まで諦めずに冒険したい & .029 & -.048 & .709 & .014 & .003 \\
\hline 危ない所へは絶対近づかない & -.044 & -.046 & .033 & .805 & .033 \\
\hline 何ごとも安全第一である & .079 & -.056 & .063 & .751 & .015 \\
\hline 怖いことは何でも嫌いである & -.008 & .135 & -.093 & .650 & -.057 \\
\hline 危険と安全が混じり合っていることで、世の中は成り立っている & -.018 & -.004 & -.040 & .046 & .845 \\
\hline 世の中のあらゆる出来事には、危険がつきまとうのはしかたがない & .006 & -.021 & -.026 & .004 & .756 \\
\hline 危険と上手につきあうのが人生である & .024 & .057 & .112 & -.093 & .518 \\
\hline 説明された分散の割合 & $24 \%$ & $20 \%$ & $11 \%$ & $9 \%$ & $6 \%$ \\
\hline
\end{tabular}

Table 5 リスク回避志向性に関する因子分析解析結果

\begin{tabular}{|c|c|c|c|c|c|}
\hline 質問文 & $\mathrm{f} 1$ & $\mathrm{f} 2$ & f3 & f4 & f5 \\
\hline $\begin{array}{l}\text { 地震、風水害、落雷などの自然災害に自分が被災するのではないかとよく心 } \\
\text { 配する }\end{array}$ & .836 & -.092 & .025 & .023 & -.029 \\
\hline $\begin{array}{l}\text { 飛行機、観光バスに乗る場合、もし大事故にあったらということを考えてし } \\
\text { まう }\end{array}$ & .725 & .106 & -.030 & -.066 & -.029 \\
\hline 何かに付けてよく心配するほうである & .629 & -.190 & .003 & .010 & .359 \\
\hline 自動車、高速バスに乗る場合、事故時に死亡率の高い座席を気にする & .577 & .295 & -.011 & .022 & -.142 \\
\hline ホテル、旅館に宿泊するとき、避難口を確認する & -.056 & .812 & -.027 & -.021 & .022 \\
\hline 住居を選ぶとき、火事に対して安全な造りであるか気になる & .007 & .684 & .080 & .005 & .066 \\
\hline 寝る前に戸締り、火の元を確認しないと心配である & .133 & .266 & .058 & .082 & .242 \\
\hline 健康には気をつけて生活をしている & -.043 & -.031 & .799 & .035 & .061 \\
\hline タバコは身体に悪いので吸わないようにしている & .007 & .035 & .474 & -.128 & -.010 \\
\hline 食品添加物合成着色料を使用している食品を極力食べない & .128 & .194 & .385 & -.001 & -.073 \\
\hline ゲームではお金をかけないと面白くない & -.011 & .034 & -.154 & .663 & .026 \\
\hline 貯蓄する場合、確定利率より変動利率のほうに魅力を感じる & -.055 & .070 & .030 & .587 & .019 \\
\hline 宝くじを買いたいと思うことがある & .038 & -.016 & -.024 & .346 & .057 \\
\hline $\begin{array}{l}\text { スキューバダイビング、ハンググライダーなどの危険なスポーツをやってみ } \\
\text { たい }\end{array}$ & -.051 & -.099 & .077 & .320 & -.155 \\
\hline もし、臨時収入 10 万円手に入ったら、先のことを考えないで使ってしまう & .116 & -.035 & -.120 & .278 & -.202 \\
\hline 雑誌などの懸賞は当たる確率が低いので、あまり応募しない & .022 & .038 & .002 & .049 & .022 \\
\hline 慎重に行動するほうである & .029 & .053 & .151 & .047 & .594 \\
\hline 友達に比べると怖いもの知らずである & .018 & -.072 & .235 & .250 & -.378 \\
\hline 説明された分散の割合 & $23 \%$ & $11 \%$ & $9 \%$ & $6 \%$ & $6 \%$ \\
\hline
\end{tabular}


法（そうだ〜そうでない）で問うた。これら個々の質問 文については結果における Table 4, 5 に示してある。

\subsection{5 個人属性}

個人属性については, 性別, 年齢, 血液型, 職業, 世 帯収入, 居住地域, 居住形態, 同居人数, 成人前の子供 と同居しているかどうか, の 9 項目を問うた。

最後にアンケートの内容や，飲料水に関する自由回答 を求めた。

\section{2 調査概要}

調査の対象は, 東京都 23 区, 熊本市の 20 歳以上の男 女とした。簡易水道や井戸水でない上水道が完備されて いる地域で調査を行うため, 対象地域を東京都 23 区と した。また, 比較地域として, 地下水を上水道水源とし,

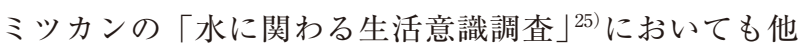
地域に比べ，水道水に対し高評価であった，熊本市も対 象とした。

また，飲料水に対して一定の自分の意見を持ち，さら に自分の判断で飲料水を選択できる年齢として, 対象年 齢を 20 歳以上とした。

調査は, (株ママクロミルのモニターに対し, オンライン アンケートにより 2010 年 12 月 15 日〜 18 日に実施し た。男女比, 年齢構成は, それぞれ対象地域ごとに東京 23 区，熊本市の 20 歳以上の住民比率に準拠した。オン ラインアンケート法は, インターネット調査会社に登録 しているモニターに対して回答を依頼し，回答データを 得る手法である。分岐質問等の質問シーケンスをコント ロールできる, 男女比と年齢構成を対象とする母集団の 住民比率に合わせてサンプリングできるといった利点を 持つ ${ }^{26)}$ 。特に提供情報ごとに質問を分岐させる本研究の ような調査を大規模に行うのに適した手法と考えられた ことから，本手法を用いた。

設計サンプル数は, 提供情報のグループごとに東京 23 区で 250 名, 熊本市で 100 名を得るものとした。

\section{3. 結果と考察}

\section{1 リスク認知の因子分析結果}

アンケートにより得られた有効回答数は, 各グループ, 東京 23 区で 258 名熊本市で 103 名 $(\times 11$ グループ $)$ の 合計 3,971 であった。

飲料水に対するリスク認知に関する回答（4 件法）を, リスク認知が高くなるほど点数が高くなるよう得点化 (4〜1) し, 因子分析によりリスク認知因子を抽出した。 最尤法および回転法にはプロマックス法を用い, 固有值 の下限は 1 とした。水道水, 浄水器, ボトル水の全ての リスク認知において，2因子が抽出された。算定された 因子負荷量を Table 3 に示す。

f1 が恐ろしさ因子, f2 が未知性因子と考えられる。水 道水を対象として「安心感 (恐ろしさの逆転表記)」因 子と, 科学的把握度を含めた「未知性」因子を主な 2 因 子として抽出した平山ら ${ }^{12)}$ の既往研究とも合致する結果 となった。水道水とボトル水で抽出された 2 因子と浄水 器で抽出された 2 因子の構成項目は若干異なった。水道 水とボトル水については, $\mathrm{f} 2$ が $\mathrm{S} 8$ に, 浄水器については, f1 がS9 に影響を与えている。浄水器は消費者のメンテ ナンスに依るところや，ほとんど使用したことがない人 がいるなど，水道水やボトル水とは異なる性質を持って
いることが原因と考えられる。2つの因子によって説明 される分散は水道水で $59 \%$, 浄水器で $65 \%$, ボトル水 で $67 \%$ であった。説明される分散の割合より, リスク認 知を主に説明しているのは恐ろしさ因子と考えられた。

\section{2 提供情報グループ別リスク認知解析結果}

\section{2.1 提供情報の信頼度}

まずは，提供情報の内容によって，情報への信頼度が 変わるかどうかを確認する。「与えられた情報は信頼で きるか」への回答結果（1：信頼できる，2：やや信頼で きる，3：あまり信頼できない，4：信頼できない）につ き，提供情報グループごとに平均值を求めた（值が高い 程「信頼できない」)。最も高い值を示したグループは, 水道水の感染事例や DALY 情報を与えた G7 の 2.23 で あり, 一方, 最も低い值を示したグループは, 水道水の 基礎情報と浄水器およびボトル水のネガティブ情報を与 えた G4の 2.01 だった。全てのグループで值は 2.5 以下 であり，提供した情報は比較的「信頼できる」と考えら れたことがわかる。また, 各グループ間での差はあまり みられず，情報が「信頼できない」ことがリスク認知を 高くした影響は無視してよいと考えられた。

一面的コミュニケーションに比べて両面的コミュニ ケーションは, くわしさの側面について効果があり, 間 接的に信頼性評価の向上をもたらすといわれている ${ }^{9)}$ 。 しかし, 今回の結果では, むしろ信頼が低くなった（G1 $(2.03) \rightarrow \mathrm{G} 2(2.11), \mathrm{G} 4(2.01) \rightarrow \mathrm{G} 5(2.16))$ 。本研究 では提供情報内容をリスク関連情報に絞ったため, 水道 水に関してポジティブ情報のみを与えることが難しく, 基礎情報もリスク情報を含むものとなった。そのため, G1，4 が完全な一面的コミュニケーションにならなかっ たことがこの原因と思われる。また，情報量を絞ったた め, くわしさの側面での評価向上がみられなかったので はないかと考えられた。

\section{2.2 追加的情報提供の影響}

提供情報別グループごとの水道水に対するリスク認知 因子得点を, Fig. 1 に, 浄水器とボトル水に対するリス ク認知因子得点を Fig. 2 に示した。

水道水, 浄水器, ボトル水のいずれにおいても情報を 全く与えない G11 に比べ, 情報を与えたその他のグルー プにおいて恐ろしさ因子得点が高くなり, 未知性因子得 点が低くなった。情報提供が未知性を減少させることは, 情報提供の有効性の一つとして挙げられており, 例え ば, Crocker ${ }^{27)}$ などにおいても同様の傾向が示されてい る。一方で, 今回提供した情報は基礎情報であってもり スクに関連した情報を含んでいたため, 一般情報を含む 全てのグループにおいて, 情報を提供しない場合に比べ て, 恐ろしさを増大させたものと考えられた。また，水 道水の情報を与えること $(\mathrm{G} 11 \rightarrow \mathrm{G} 1)$ が, 浄水器抢よ びボトル水のリスク認知にも影響を与えていた。これは, 水道水のリスク情報が, 飲料水全体にも拡張して捉えら れたためではないかと考えられる。

水道水のリスク認知の結果をみてみると（Fig. 1), 情 報提供群の中では，基礎情報のみを与えた $\mathrm{G} 1$ に対し， その他のグループにおける恐ろしさ因子得点がいずれも 高くなっている。これは, DALY や感染事例などの追加 的情報がいずれもリスクを喚起するものとなったことを 示している。浄水器およびボトル水においても (Fig. 2), 


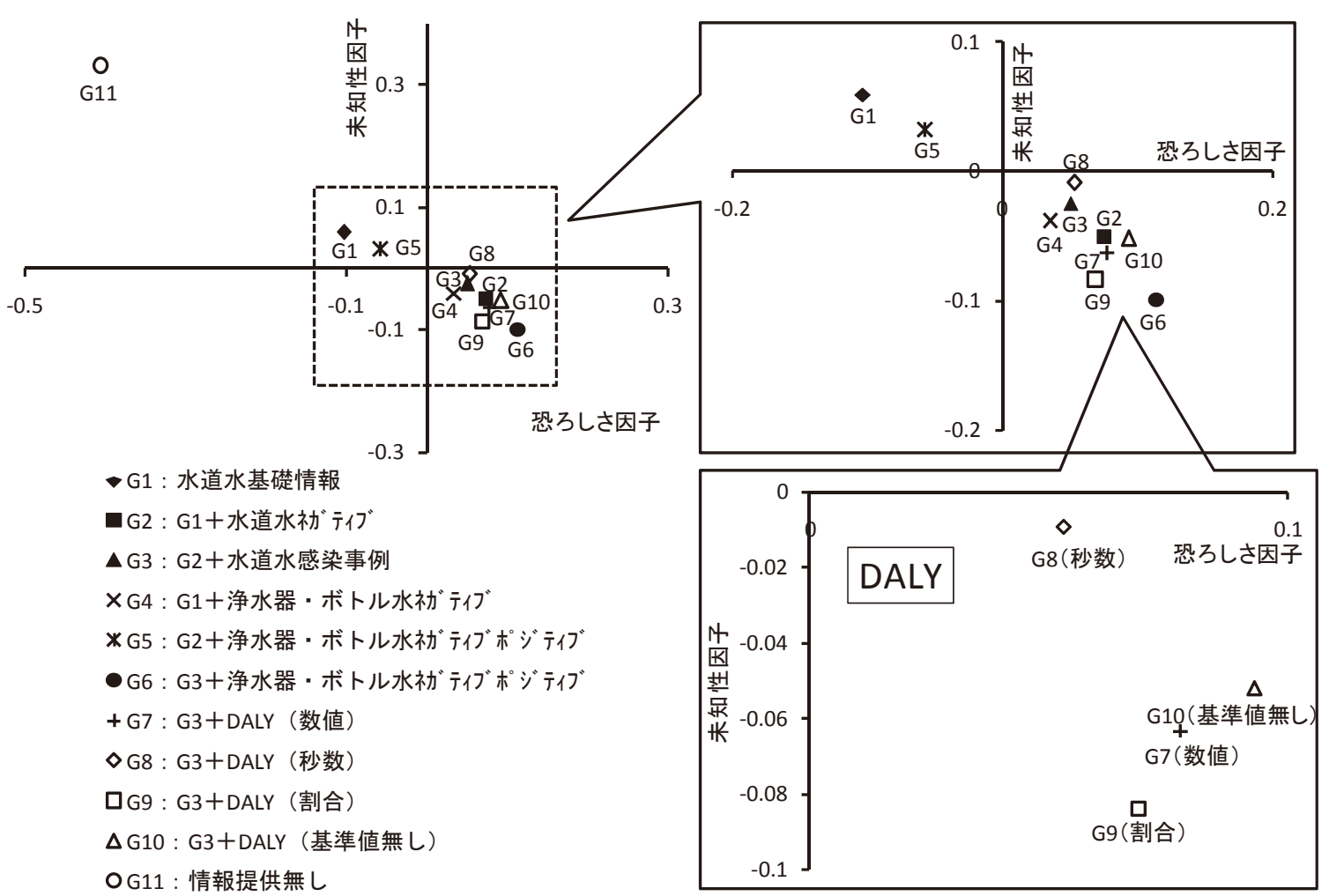

Fig. 1 提供情報グループ別水道水リスク認知

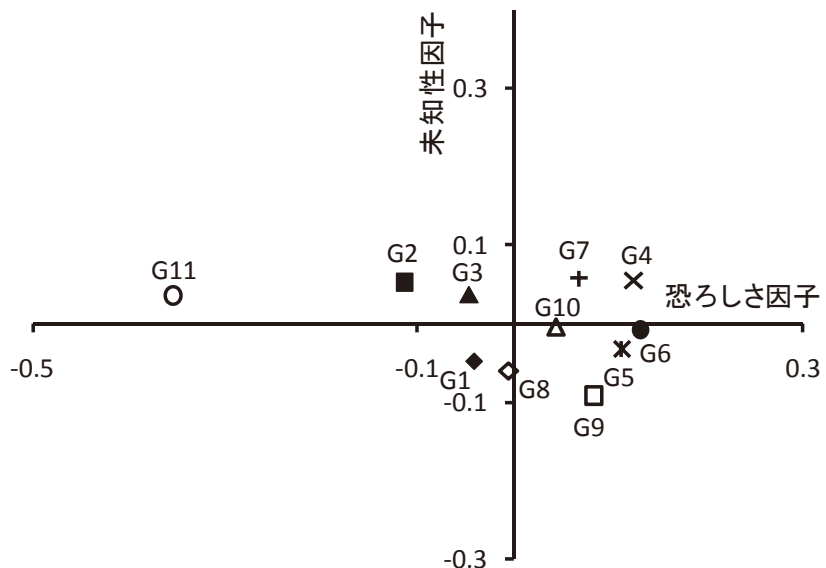

Fig. 2 浄水器およびボトル水に対するリスク認知 (左 : 浄水器, 右 : ボトル水)
それぞれに固有の情報をえた G4〜6において恐ろしさ 因子得点が高くなった。

ネガティブ情報のみを与えた場合（G4）とポジティ ブ情報を追加した場合（G5，6）を比べてみると，恐ろ しさ因子得点には大きな違いは見られず，浄水器の未知 性においてのみ G4 が高くなっている。今回の情報提供 に含まれたリスク喚起情報は全てネガティブな影響を持 ち，ポジティブ情報の効果は見られなかったと考えられ る。一般的にも，ポジティブな情報よりネガティブな情 報の方がより強い影響をもつことが知られている ${ }^{28)}$ 。ま た，原子力技術のリスクを扱った既往研究においても， 両面的提示でもリスク認知に変化はなく ${ }^{10,11)}$, 本研究に おいても，同様の結果となった。

\section{2.3 数值情報の影響}

(1) DALY

G3 に対して, DALY 情報を加えた G7 〜 10 において, 若干ではあるが，未知性因子得点が低くなると共に，恐
ろしさ因子が高くなった。

広田 ${ }^{7)}$ は，ベースレートを明示しない場合にはリスク が大きくみられてしまうことを示している。特にリスク が絶対的に低い場合には，比較対象を同時に提示し相 対判断を求めることが重要である，としている。Fig. 1 の右下の拡大図よりDALYの示し方による違いを見て みると $(\mathrm{G} 7 \sim 10)$ ，值や割合で情報提示する（G7，9） よりも秒数で示した（G8）際に, 恐ろしさ因子得点の $\mathrm{G} 11$ からの増加度合いが小さく, さらに, WHO の基準 值を示さない場合（G10）に，若干ではあるが, 恐ろし さ因子得点の増加度合いが高くなった。

今回扱ったリスクは絶対值の低いものであり, 日常的に 使われる時間単位を用いること（G8）で，その他の単位 を用いた場合より相対判断がしやすくなり, リスクに対す る恐れの認識が小さくなったのではないかと考えられた。

\section{(2) 集団感染事例}

水道水については, G5 と G6 に大きな差がある一方, 
G2 と G3 で差が見られないため, 集団感染事例提示の 有無によるリスク認知への影響があるとはいえない。

しかし, 被験者が集団感染事例を多いと感じるかどう かによってリスク認知に影響が出る可能性が考えられ る。そこで, 集団感染事例提示に引き続き, 同事例数が 多いと思ったかどうか（はい，いいえ，わからない）の 回答ごとにリスク認知因子得点の平均值を求めた（Fig. 3)。その結果, はい, わからない, いいえの順に恐ろし さ因子得点が高くなり, 未知性因子得点はその逆となっ た。これにより, 同じ数值情報であっても, 受け手がそ れをどう捉えるかによってリスク認知が影響されること がわかる。

\section{2.4 情報提供後の飲料水の選択}

情報提供の後, 「水道水, 浄水器, ボトル水のうちな らばいずれを飲みたいか」を問うた結果を, 提供情報グ ループ別に Fig. 4 に示す。

情報提供後の飲料水選択は，提供情報グループごとに 有意に差が見られた $\left(\chi^{2}\right.$ 值 $\left.=44.6, \mathrm{p}=.001\right)$ 。ネガティ ブ情報を与えること（水道水：G2，3，ボトル水：G4 〜 6) で, 対象の水を飲みたい人が減っていることが分 かり, 情報提供による飲料水選択への影響が示唆された。

\section{3 情報提供前飲料水志向の影響}

\section{3.1 頻度}

情報提供前の，飲料水を飲む頻度に関する回答グルー プ（4 件法）ごとの恐ろしさ因子得点を，Fig. 5 に示す。

特に水道水を飲む頻度が高い回答者ほど水道水恐ろし さ因子得点が低く, ボトル水恐ろしさ因子得点が高く なっていることがわかる。その他の水においては概ねこ れと逆の傾向となっており, ボトル水や浄水器, サーバー の水を飲む頻度が高い回答者ほど, 水道水の恐ろしさ因 子得点が高い。つまり, 飲料水選択の決定因子は水道水

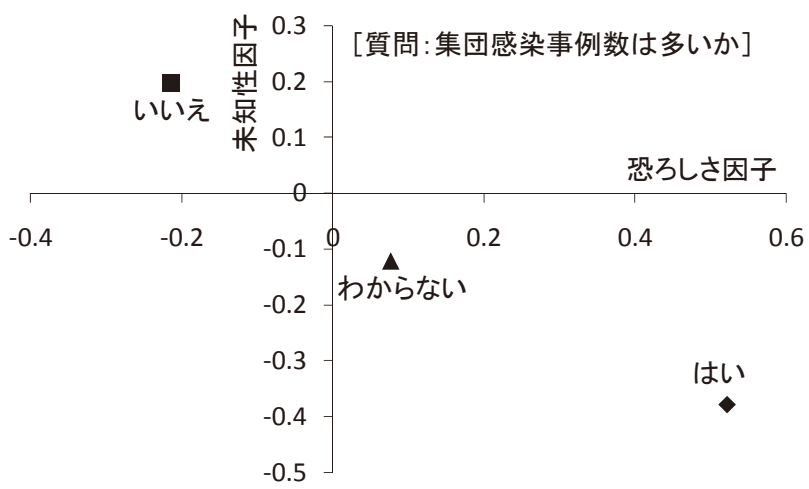

Fig. 3 集団感染事例の捉え方とリスク認知の関係

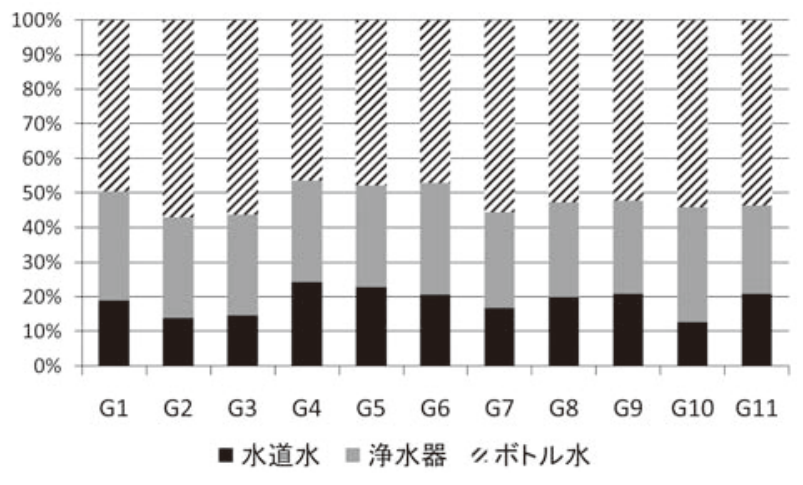

Fig. 4 情報提供後飲料水選択
に対する恐ろしさであると考えられる。

Fig. 6 では，情報提供前に水道水を「あまり飲まない」 あるいは「ほとんど飲まない」と答えたが, 情報提供後 に今後「水道水」を飲みたいと答えた回答者の割合を, 提供情報グループごとに示した。情報提供前後で水道水 に対する意見を変えた割合は, 全体で $3.8 \%$ だった。水 道水の基礎情報に加えて, 浄水器とボトル水のネガティ ブ情報を与えた場合（G4）に，水道水へ意見を変えた 割合が高かったものの, 提供情報グループごとに有意な 差は見られなかった（ $\chi^{2}$ 值 $=13.3, \mathrm{p}=.206$; Yate's の 補正後の值)。

\section{3.2 味への認識}

情報提供前の, 飲料水への味の認識に関する回答グ ループ (4 件法) ごとの恐ろしさ因子得点を, Fig. 7 に 示す。

水道水と浄水器の味への認識が良い回答者ほど水道水 および浄水器の恐ろしさ因子得点が低く, ボトル水の恐 ろしさ因子得点が高くなっていることがわかる。ボトル

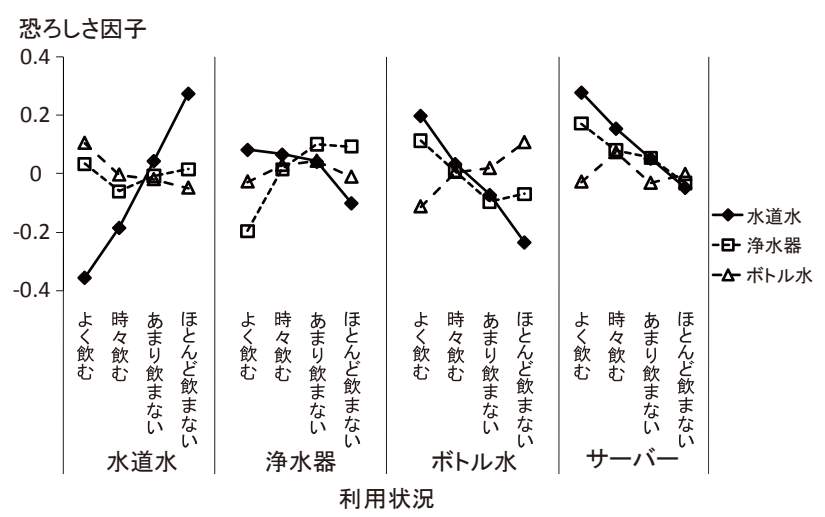

Fig. 5 飲料水利用状況と恐ろしさ因子得点との関係

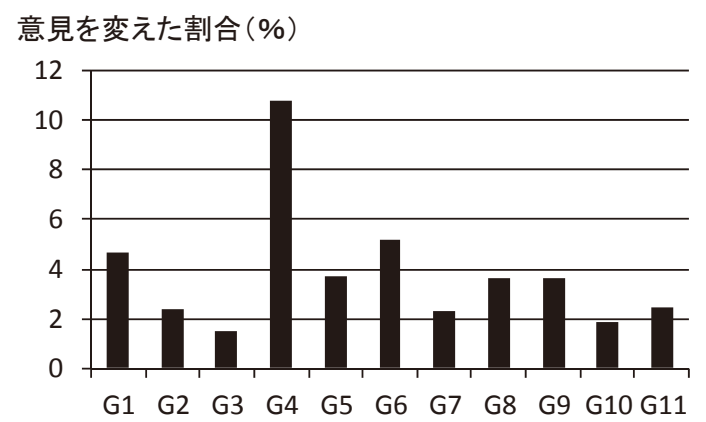

Fig. 6 情報提供前後での水道水選択への変化割合

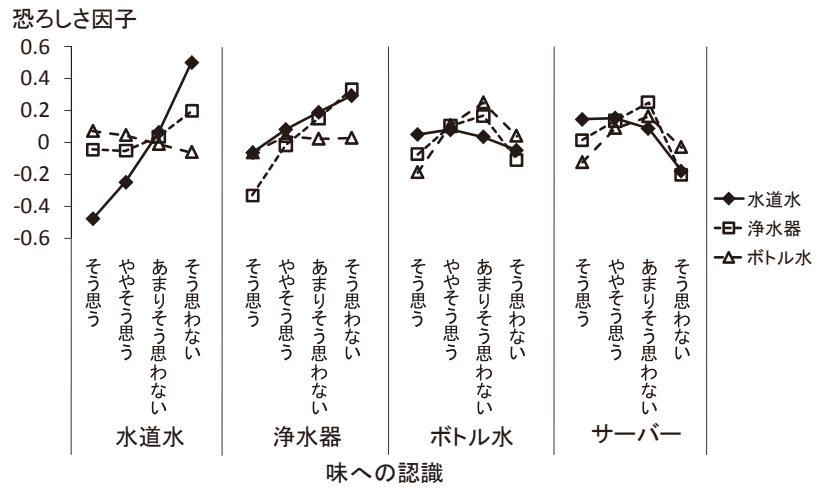

Fig. 7 味への認識と恐ろしさ因子得点との関係 
水, サーバー水の味への認識が良い回答者は, 水道水の 恐ろしさ因子得点が高くなっていた。

\section{4 個人特性のリスク認知への影響}

3.4.1 リスク受容性とリスク回避志向性の因子分析 結果

ここでは個人特性のリスク認知への影響を見る。まず， リスク受容性を示す因子を抽出するため, リスク受容尺 度（SRA）の回答に対し, 最尤法およびプロマックス法 による回転, 固有值の下限を 1 とした因子分析を行った。 既往研究 ${ }^{23)}$ と同じく5つの因子が抽出され，71\%の分散 が説明された。算定された因子負荷量を Table 4 に示す。 木下ら ${ }^{23)}$ と同様に, f1 は「慎重さ」, f2 は「無謀さ」, f3 は「チャレンジング」, f4 は「安全第一」, f5 は「運命」 と名付けられる。リスクを受動的にとらえるのが「運命」 であり，抑制的ではあるが能動的に対応するのが「慎重 さ」および「チャレンジング」, さらに能動性が極端な のが「安全第一」と「無謀さ」であるとされる ${ }^{23)}$

リスク回避志向性に関しても, 同様の因子分析を行っ たところ，5つの因子が抽出された。算定された因子負 荷量を Table 5 に示す。 5 つの因子によって 55\%の分散

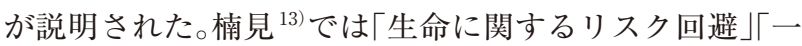
般的な不安」「金銭リスク志向」の 3 因子が抽出されたが, 本分析では以下の 5 因子を抽出することが妥当と考えら れた。 f1 が「心配症」, f2 が「火災リスクを重視する傾向」, f3 が「健康リスクを重視する傾向」, f4 が「ギャンブル性」, $\mathrm{f} 5$ が「慎重さ」を示す因子といえる。

3.4.2 リスク特性と恐ろしさ因子の関係性

各リスク受容性因子の因子得点と水道水の恐ろしさ因 子との関係を Fig. 8 に示す。因子得点は回答者数によっ

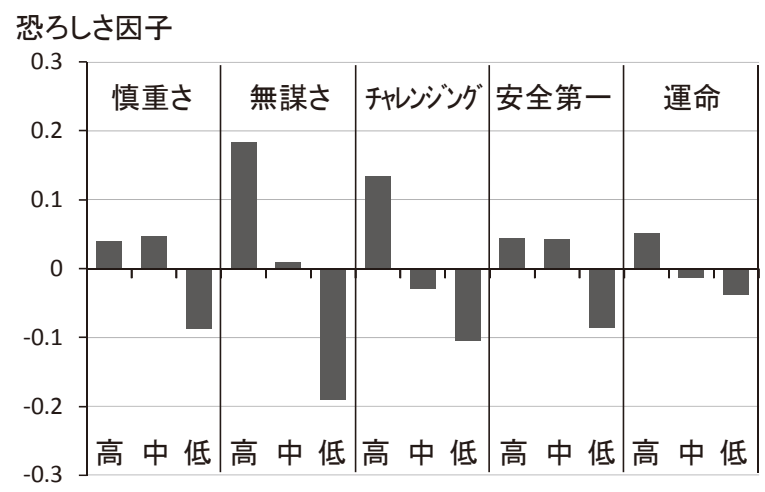

Fig. 8 SRA 各因子と水道水の恐ろしさ因子との関係
て得点の高い順に三つのグループに分けた。特に「無謀 さ」因子が高いほど恐ろしさ因子が高くなっている。さ らに,「チャレンジング」因子にも同様の傾向がみられた。 木下ら ${ }^{24)}$ は, 「無謀さ」因子と「チャレンジング」因子 が高い被験者は，一人旅や冒険的なスポーツを好むなど 高いリスクに対して能動的かつ積極的に対応するとして おり，そのためリスクを高く認知するのではないかと考 えられた。

リスク回避志向性についても, SRA と同様に回答者 数によって因子得点の高い順に三つのグループに分け, それぞれの水道水恐ろしさ因子得点の平均值を求めた (Fig. 9)。すべての因子において, 各因子が高くなるに 伴い恐ろしさ因子が高くなる関係が見て取れる。その傾 向が顕著なのは「心配症」因子と「火災リスク重視」因 子であった。

「慎重さ」因子が低い場合に恐ろしさ因子得点が低く なる傾向はSRA およびリスク回避志向性の二つの異な る尺度においても同様に示された。恐ろしさ因子に対し てょり顕著に影響を示したのはSRA ではなくリスク回 避志向性であった。リスク回避志向性は, 手術や海外旅 行事故等のリスク回避行動に大きく影響を及ぼすとさ れ ${ }^{13)}$, リスクを回避する程度をはかる指標と考えられる ため，より本質的な性格をあらわす SRAよりもリスク 認知と強く相関したのではないかと考えられる。

\section{4.3 個人特性の提供情報認知に与える影響}

リスク受容性とリスク回避志向性において, 各因子得 点の平均值からの高低で回答者を 2 群に分け, 各群での 提供情報がリスク認知に与える影響を見た。情報提供群 （G1 ～G10）については, まとめてひとつとして扱った。

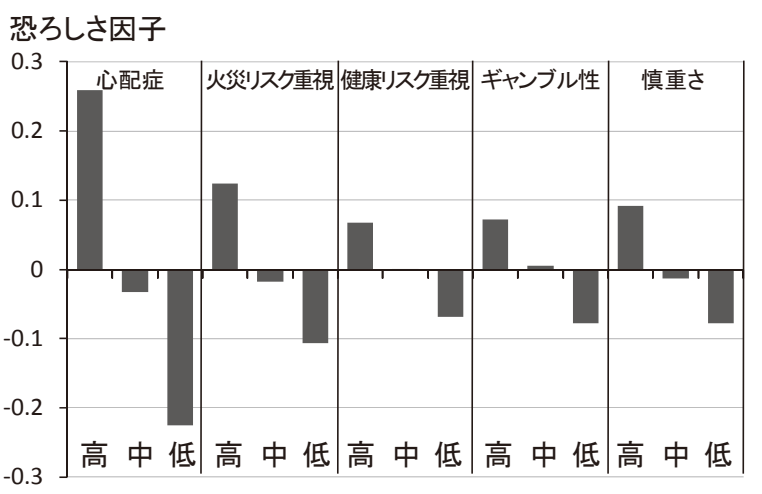

Fig. 9 リスク回避志向性と水道水の恐ろしさ因子との関係

Table 6 SRA と提供情報認知の関係

\begin{tabular}{|c|c|c|c|c|c|c|c|}
\hline \multirow{2}{*}{\multicolumn{2}{|c|}{ 情報提供 $\rightarrow$}} & \multicolumn{3}{|c|}{ 恐ろしさ } & \multicolumn{3}{|c|}{ 未知性 } \\
\hline & & 有 & $\begin{array}{l}\text { 無 } \\
\end{array}$ & 差 & 有 & $\begin{array}{l}\text { 無 } \\
\end{array}$ & 差 \\
\hline \multirow{2}{*}{ 慎重さ } & 高 & 0.11 & -0.25 & 0.36 & -0.09 & 0.18 & -0.28 \\
\hline & 低 & -0.03 & -0.56 & 0.54 & 0.03 & 0.47 & -0.45 \\
\hline \multirow{2}{*}{ 無謀さ } & 高 & 0.17 & -0.37 & 0.55 & -0.16 & 0.30 & -0.46 \\
\hline & 低 & -0.09 & -0.44 & 0.36 & 0.10 & 0.37 & -0.27 \\
\hline \multirow{2}{*}{ チャレンジング } & 高 & 0.12 & -0.30 & 0.43 & -0.10 & 0.25 & -0.35 \\
\hline & 低 & -0.04 & -0.54 & 0.50 & 0.04 & 0.43 & -0.40 \\
\hline \multirow{2}{*}{ 安全第一 } & 高 & 0.09 & -0.32 & 0.41 & -0.09 & 0.24 & -0.32 \\
\hline & 低 & -0.01 & -0.48 & 0.46 & 0.02 & 0.40 & -0.38 \\
\hline \multirow{2}{*}{ 運命 } & 高 & 0.08 & -0.41 & 0.49 & -0.06 & 0.31 & -0.37 \\
\hline & 低 & 0.00 & -0.40 & 0.40 & -0.01 & 0.35 & -0.36 \\
\hline
\end{tabular}


Table 7 リスク回避志向性と提供情報認知の関係

\begin{tabular}{|c|c|ccc|ccc|}
\hline \multirow{2}{*}{\multicolumn{2}{|c|}{}} & \multicolumn{3}{|c|}{ 恐ろしさ } & \multicolumn{3}{c|}{ 未郝性 } \\
\cline { 2 - 8 } 提供 & 有 & 無 & 差 & 有 & 無 & 差 \\
\hline \multirow{2}{*}{ 心配症 } & 高 & 0.21 & -0.22 & 0.43 & -0.18 & 0.19 & -0.36 \\
& 低 & -0.13 & -0.58 & 0.45 & 0.11 & 0.47 & -0.36 \\
\hline \multirow{2}{*}{ 火災リスク重視 } & 高 & 0.11 & -0.30 & 0.41 & -0.10 & 0.23 & -0.33 \\
& 低 & -0.03 & -0.52 & 0.49 & 0.03 & 0.44 & -0.41 \\
\hline \multirow{2}{*}{ 健捸リスク重視 } & 高 & 0.09 & -0.32 & 0.41 & -0.09 & 0.26 & -0.35 \\
& 低 & -0.01 & -0.50 & 0.49 & 0.02 & 0.40 & -0.38 \\
\hline \multirow{2}{*}{ ギャンブル性 } & 高 & 0.10 & -0.43 & 0.53 & -0.12 & 0.33 & -0.45 \\
& 低 & -0.02 & -0.39 & 0.36 & 0.05 & 0.33 & -0.28 \\
\hline \multirow{2}{*}{ 慎重さ } & 高 & 0.09 & -0.32 & 0.41 & -0.06 & 0.28 & -0.35 \\
& 低 & -0.01 & -0.48 & 0.47 & 0.00 & 0.37 & -0.38 \\
\hline
\end{tabular}

Table 6 および 7 に結果を示す。

「無謀さ」因子の高い群では, 情報を提供することに よって未知性因子得点が 0.46 減少し, 恐ろしさ因子得 点が 0.55 増加するのに対して,「無謀さ」因子が低い群 では, 未知性が 0.27 の減少, 恐ろしさが 0.36 の増加となっ ており,「無謀さ」の高い群の方が, よりリスク認知へ の情報提供の影響が大きくなっていることがわかる。同 様な傾向は, 「運命」, リスク回避志向性における「ギャ ンブル性」の因子においても見られている。

これに対し，リスク受容性における「慎重さ」因子が 高い群では, 情報提供によって未知性因子得点が 0.28 減少し, 恐ろしさ因子得点が 0.36 増加するのに対し,「慎 重さ」因子が低い群では, 未知性が 0.45 減少し, 恐ろ しさが 0.54 増加し, 「慎重さ」の低い群の方が, リスク 認知への情報提供の影響が大きいことがわかる。リスク 回避志向性における「慎重さ」,「火災リスク重視」,「健 康リスク重視」の因子でも同様の傾向が見られている。

これらのことより, リスク情報提供に伴う今回の「未 知性」の減少および「恐ろしさ」の増加の影響は,「無謀さ」 「運命」「ギャンブル性」の高い群, すなわちリスクを高 く捉えていても行動を起こすような群や,「慎重さ」が 低い群において，その影響が大きいことが分かった。

\section{5 個人属性別リスク認知解析結果}

\subsection{1 個人属性の恐ろしさ因子に与える影響}

さらに個人属性のリスク認知への影響をみるため, 個 人属性ごとに被験者をグループに分け，それぞれの水 道水に対する恐ろしさ因子得点の平均值を求めた（Fig. 10)。

年齢別では, 年齢が低い人ほど, 恐ろしさ因子得点が 高い。年歯令と飲料水の飲む頻度, 味への認識に相関はみ られなかったため, 年齢そのものがリスク認知に影響し ていると考えられる。若年層程リスク認知が高い傾向は 新型インフルエンザに関するリスクを扱った三島の研 究 ${ }^{29)}$ においても示されている。

世帯収入については, 一般的には年齢との相関が考え られるが本調查では年齢と世帯収入の相関は高くなかっ た $(\mathrm{r}=0.124)$ 。ょって，世帯収入が高くなるほど，リ スクを低く捉えているということができる。

男性と女性とでは，女性がリスクを高く捉えている。 松本ら ${ }^{30)}$ は, スモッグに対する健康リスク認知の性差に ついて, 同様に女性の方が高いという傾向を示している。

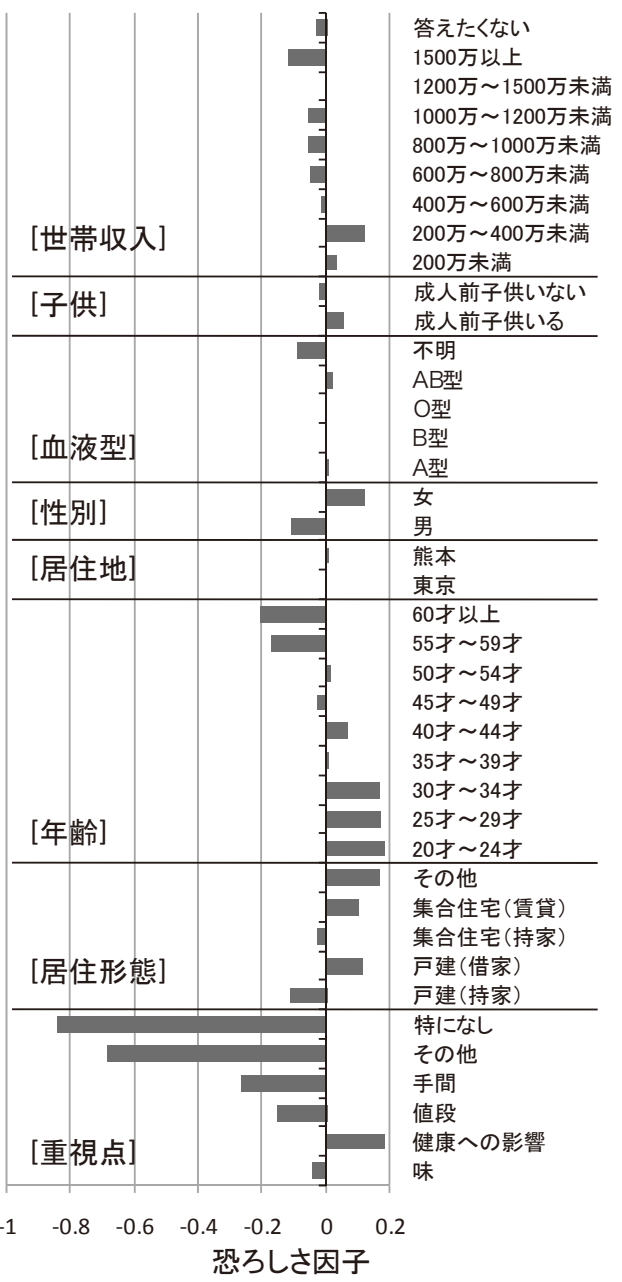

Fig. 10 個人属性別水道水リスク認知

血液型の感染症への影響として生理学的感染力の違い に加えて, 行動パターン等への影響も指摘されてはい

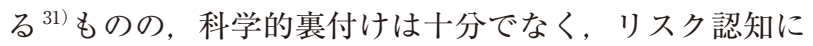
与える血液型の影響を議論することは適切とはいえな い。ただし，ここでは特に「自分の血液型を知らない」 と回答した群におけるリスク認知が顕著に低いことが, 興味深い結果といえる。

飲料水において重視する点は, 評価した個人属性の中 で最も影響が大きく，特に健康への影響を第一に考えて いる回答者の恐ろしさ因子得点が高い。リスク回避志向 性においても, 健康リスク重視因子得点と恐ろしさ因子 
には正の相関があり，妥当な結果といえた。

\section{5.2 個人属性が提供情報認知に与える影響}

3. 5.1 で示したリスク認知に影響を持つ個人属性の中 で，特に性差と年齢を取り上げ，その違いが情報認知に もたらす影響を見ることとした。年齢については, 20 才〜 34 才, 35 才〜 49 才, 50 才以上の 3 群に分け比較 した。Fig. 11 に性差による影響を，Fig. 12 に年齢によ る影響を示す。

女性における情報提供前後でのリスク認知の変化は, 恐ろしさ因子：0.40 増加, 未知性因子：0.33 減少であっ たのに対し，男性では，恐れ：0.50 増加，未知性 : 0.40 減少と, 男性の方が若干ではあるが, 情報のリスク認知 に対する影響が大きいことがわかる。

さらに，年齢別で比較すると，若年層は情報提供前か らリスク認知が高く，情報提供の影響は他の年代と比べ て小さいことがわかった。このように，個人属性の影響 は, 情報提供前のリスク認知が低い男性や高年齢層にお いて特に大きくなることが分かる。

\section{6 総合考察}

本研究で掲げた 4 つの論点につき, 考察を加える。

1）情報がリスク認知に与える影響としては, 水道 水, 浄水器, ボトル水のいずれにおいても情報を全 く与えない G11に比べ，情報を与えたその他のグ ループにおいて，未知性因子が低下する一方，恐乃 しさ因子得点が高くなった。未知性を下げることは, 情報提供のひとつの有効性といえる。水道水のリス ク認知の結果をみてみると (Fig. 1), 情報提供群の 中では，基礎情報のみを与えたグループに対し，そ の他のグループにおける未知性得点が低く, 恐ろし さ得点が高くなった。情報量がリスク認知にもたら

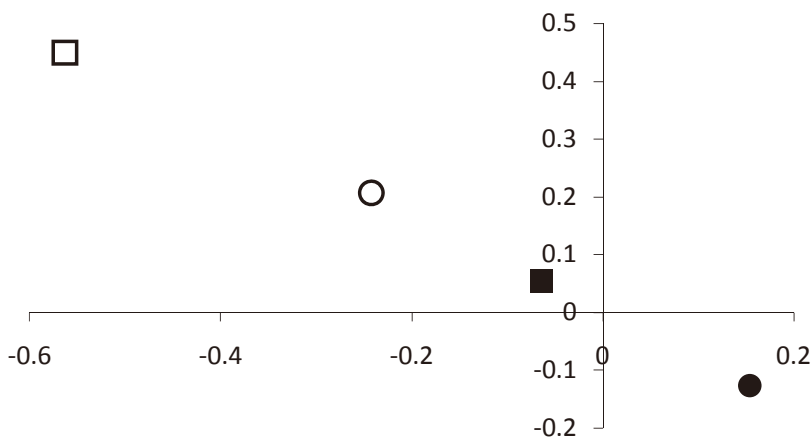

一男性情報有口男性情報無 -女性情報有 ○女性情報無

Fig. 11 性差と提供情報認知の関係

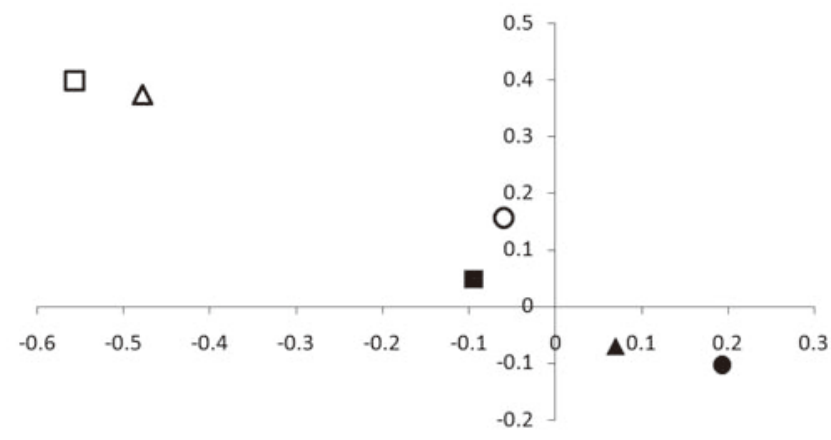

・20才〜34才情報有O20才〜34才情報無㟔35才〜 49才情報有 $\Delta 35$ 才 49 才情報無 -50 才以上情報有 050 才以上情報無

Fig. 12 年齢と提供情報認知の関係
す影響については, 例えば Crocker. ${ }^{27)}$ は情報量の多 さがリスク認知や選択にポジティブな影響をもたら すとしている一方で，メディアによる度重なる報道 がリスクを過剩に認知させてしまうという研究 ${ }^{32} も$ ある。本研究においても, 追加的なさまざまなリス ク情報が，リスク認知に影響を与えたといえる。

2) 一面的コミュニケーションに比べて両面的コ ミュニケーションは, リスク認知は変化させない

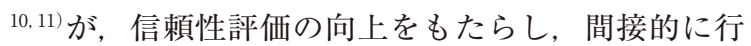
動に影響を与えるともいわれている ${ }^{9)}$ 。しかし，今 回の結果では, 基礎情報にさらにネガティブ情報を 追加することで, 信頼が低くなり, 恐ろしさ因子得 点が高くなる影響が見られた。これは, 本研究での 提供情報がリスクに関する情報であり，水道水に関 してポジティブ情報のみを与えることができなかっ たため, 両面的コミュニケーションではなく，むし ろ恐怖喚起コミュニケーションとなってしまったこ とが原因と考えられる。一方で, 恐怖喚起コミュニ ケーションであっても, リスク認知における未知性 が減少することは情報提供の有効性を示唆している ともいえる。また, ボトル水と浄水器において, ネ ガティブ情報のみを示した場合と, ポジティブ情報 を追加した場合においても顕著な差は見られなかっ た。通常人はネガティブ情報をポジティブ情報より 大きく認知するとも言われており, 本研究でもネガ ティブ情報のリスク認知への影響が主となり，ポジ ティブ情報の影響はほとんど得られなかったと考え られる。そのため, 特に, リスクコミュニケーショ ンの実際においては, いかにポジティブ情報を有効 に伝えていくかが大きな課題であると考えられた。

3）本研究で示した数值情報の表現法の違いによる 影響は, 情報提供の有無や個人属性と比べて非常に 小さかった。しかし, 集団感染事例に関する情報に ついては, 同じ情報であっても内容の受け取り方に よってリスク認知に大きな影響が出ることが分かっ た。また, DALY 情報についてはリスクの絶対的な 值が小さく, 理解できなかった回答者が多かったと も考えられる。広田 ${ }^{7)}$ は, 確率や頻度の数值での伝 達にバイアスが存在することから, グラフ表現を用 いて伝達することの有効性を述べており, さらに, 確率や頻度を単純にグラフ化したものより, 人型グ ラフなど, 文脈性を加えたグラフ表現のほうが回答 者に受け入れられやすい傾向があると述べている。 今後このような表現法の工夫についても検討を重ね る必要がある。

4）個人特性や個人属性の中で, 恐ろしさ因子への影 響が大きかった因子は，リスク受容性における「無 謀さ」因子, リスク回避志向性における「心配症」 因子, 飲料水選択で重視する点, 性差, 年歯令, であった。 提供情報のリスク認知に与える影響については，特に 「無謀さ」「ギャンブル性」「運命」因子の高い群や，「慎 重さ」が低い群, 男性や高年歯層において, その影響が 高いことが分かった。情報に対する反応の違いとしては, 例えば安井ら ${ }^{33)}$ は環境情報に対する反応は年齢や性別よ りも環境意識が影響することを示しており，また，情報 を探索, 収集し, 保有することへの欲求に対しても, 年 
齢や性差による影響は示されていない ${ }^{34)}$ 。今回の結果に おいても，個人属性の影響に比べ，個人特性のもたらす 影響の方が大きいことが示されている。また, リスク特 性の違いによる提供情報認知への影響を検討している既 往研究例は見られなく, 飲料水に対象が限定されてはい るものの, 本研究で得られた知見は興味深いものである といえる。

\section{4. おわりに}

本研究では, 情報を提供することがその内容や示し方 によってリスク認知にどのような影響を与えるかを明ら かにすることを目的とし, 飲料水を例として提供情報の 影響を見た。さらに, 個人特性や個人属性の影響も評価 した。

情報を提供しない群に比べ，情報を提供した群におい て総じて恐ろしさ因子得点が高くなったことは, 今回の 情報提供が説得的コミュニケーションのうちの恐怖喚起 コミュニケーションに近いものになってしまったことを 示している。近年食の安全に対する関心が高まるにつれ, 食品・飲料水分野においては, トレーサビリティが担保 され, さらに添加物や農薬等の健康リスクに関連する客 観的情報が透明性を持って示されることが重要となって きている。飲料水に関していえば，どの水源からどのよ うに水が供給されているのか, といった情報だけでなく, さらに，飲料水に含まれる健康リスクをもたらす物質に はどのようなものがあるか，それに対しどのように対策 を行い, どのような水質が担保されているのか, といっ たリスクに関する情報が客観的に示されることで，市民 の理解を得て, 過剩な不安感を減ずることが必要といえ る。今回の結果においても, 情報提供により未知性因子 得点が減少したことは, 市民の理解を得る上で有効で あったといえる。しかし, 一方で恐ろしさ因子得点は増 加したことから, リスクに関する情報を提供する場合に は，その情報提供が市民の不安感を高めてしまう可能性 があることがわかる。リスクに関する情報においては, 安全性を示すポジティブ情報でもリスク認知を低減させ る効果は見られず, 今後リスクに関する情報だけでなく, ベネフィットに関する情報を併せてどのように市民に提 供してゆけば効果的なのか検討することが必要であると いえる。

また，客観的情報であっても，今回示したような集団 感染事例やDALY などの数值情報の場合には, 回答者 が值を理解できるかどうかも重要と考えられる。市民と のより良いコミュニケーションを目指すには, 図を用い たり，市民にとって身近な事例との比較を用いたりする など，表現方法を工夫し，回答者にとって理解しやすい 形で提示する必要性も示しているといえる。

さらに個人特性や個人属性の違いによって, 提供情報 の捉え方も異なることが示されたことから, 受け手の特 性を無視した画一的な情報提供ではなく，受け手の特性 に応じた情報提供が有効であろうと示唆された。

（原稿受付 2012 年 4 月 10 日） （原稿受理 2012 年 9 月 30 日）

\section{参 考 文 献}

1 ）益永茂樹（2007）序章リスク評価－選択の基準,「科学技術から
みたリスク」(益永茂樹編), pp.1-10, 岩波書店, 東京.

2) 関澤純 (2003) リスクコミュニケーションの最新動向を探る, $351 \mathrm{pp}$., 化学工業日報社, 東京.

3 ) Beuret, C., Kohler, D., Baumgartner, A. and Lüthi, T. M. (2002) Norwalk-Like Virus Sequences in Mineral Waters: One-Year Monitoring of Three Brands, Applied and Environmental Microbiology, $68(4), 1925-1931$.

4 ) Lamothe, G. T., Putallaz, T., Joosten, H. and Marugg, J. D. (2003) Reverse Transcription-PCR Analysis of Bottled and Natural Mineral Waters for the Presence of Noroviruses, Applied and Environmental Microbiology, 69 (11), 6541-6549.

5 ) Sanchez, G., Joosten, H., Meyer, R. and Beuret, C. (2005) Letter to the Editor Presence of Norovirus Sequences in Bottled Waters if Questionable, Applied and Environmental Microbiology, 71 (4), 22032205.

6 ) Slovic, P. (1987) Perception of Risk, Science, 236, 280-285.

7 ）広田すみれ（2005）リスク表現によるコミュニケーション効果 の違いー最近の動向一, 日本リスク研究学会誌, 15 (2), 91-96.

8 ) Gigerenzer, G. and Hoffrage, U. (1995) How to Improve Bayesian Reasoning Without Instruction: Frequency Formats, Psychological Review, 102 (4), 684-704.

9 ) 吉川肇子 (2007) 第6章リスク・コミュニケーション,「社会生 活からみたリスク」(今田高俊編), pp.127-147, 岩波書店, 東京.

10）木下富雄, 吉川肇子 (1989) リスク・コミュニケーションの効 果 (1), 日本社会心理学会第30回大会発表論文集, 109-110.

11）木下富雄, 吉川肇子 (1989) リスク・コミュニケーションの効 果 (2), 日本社会心理学会第30回大会発表論文集, 111-112.

12）平山修久, 伊藤禎彦, 加川孝介 (2004) 需要者の水道水に対す るリスク認知における構成概念の構造に関する分析, 土木学会 論文集, 755 (7-30), 75-84.

13）楠見孝 (1994) 不確実事象の認知と決定における個人差, 心理 学評論, 37 (3), 337-356.

14）金子光美 (2006) 水道の病原微生物対策, 255pp., 丸善株式会社, 東京.

15) 一般社団法人浄水器協会 (2010) 浄水器について information, http://www.jwpa.or.jp/jwpa_tmp/kyokai.htm (2012年3月現在).

16）間中友美, 後藤政幸, 古畑公 (2008) 家庭用簡易浄水器処理に よる水道水中の揮発性有機化合物濃度の変化 $-\mathrm{GC} / \mathrm{MS}$ 法による 検討 -, 和洋女子大学紀要, 48, 65-73.

17) Matsui, T., Kajima, J. and Fujino, T. (2004) Removal Effect of the Water purifier for Home Use against Cryptosporidium parvum Oocysts, The Journal of Veterinary Medical Science, 66 (8), 941-943.

18）篠原寿子, 饭盛勝義 (2006) 中津市近郊の湧水, 水道水㧍よび 市販ミネラルウォーター類の水質評価, 研究紀要, 11, 15-24.

19）後藤政幸, 荒卷輝代, 芳原達也 (2002) 小型ペットボトル飲料 を唾液㧍よび手指で污染させた時の細菌数の変化, 和洋女子大 学紀要, 42, 29-37.

20) Oie, S., Matsuzaka. Y., Kiyonaga, H., Maeda, K. and Kamiya, A. (2007) Microbiological Safety of Bottled Mineral Water in Patients Susceptible to Infections, J. Food Hyg. Soc. Japan, 49 (4), 308-310.

21) Masago, Y., Katayama, H., Watanabe, T., Haramoto, E., Hashimoto, A., Omura, T., Hirata, T. and Ohgaki, S. (2006) Quantitative Risk Assessment of Noroviruses in Drinking Water Based on Qualitative Data in Japan, Environmental Science \& Technology, 40 (24), 74287433.

22）木村昌弘 (2008) 総合評価指標を用いた次世代に向けての上下 水道システムの再構築に関する研究, 京都大学大学院工学研究 科都市社会工学専攻後期博士課程論文.

23）木下富雄, 吉野絹子（2007）リスク受容尺度（SRA）の10年間 の変化 (1) - 受容得点と因子構造は変わったか, 日本社会心理 学会第48回大会発表論文集, http://www.wdc-jp.biz/jssp/archive/ paper_download.php?s=2007-E-0398 (2012 年3月現在).

24）木下冨雄, 吉野絹子 (2007) リスク受容尺度 (SRA)の10年間 の变化 (2) - 行動は保守化したか, 日本社会心理学会第 48 回大 会発表論文集, http://www.wdc-jp.biz/jssp/archive/paper_download. php?s=2007-E-0205 (2012年3月現在).

25）ミッカン (2010) 第 16 回 (平成 22 年度)「水にかかわる生活意 識調查」結果レポート, http://www.mizu.gr.jp/images/main/chousa/ ishiki/2010/kekka2010.pdf (2012年3月現在). 
26）大塚佳臣, 栗栖聖, 中谷隼, 花木啓祐（2011）水辺意識に 着目した住民の都市河川金銭価值評価解析, 水環境学会誌, 34 (2), 29-40.

27) Crocker, K. E. (1986) The Influence of the Amount and Type of Information on Individuals' Perception of Legal Services, Journal of the Academy of Marketing Science, 14 (4), 18-27.

28) Peelers, G. and Czapinski, J. (1990) Positive-Negative Asymmetry in Evaluations: The Distinction Between Affective and Informational Negativity Effects, European Review of Social Psychology, 1, 33-60.

29）三島和子 (2010) 新型インフルエンザのリスク認知とリスクコ ミュニケーションのあり方に関する調查研究, 日本リスク研究学 会誌, 20 (1), 59-68.
30）松本晶子, 小田亮, 五百部裕 (2005) 健康リスク認知にみられ る性差の検討, 沖縄大学人文学部紀要, 6, 117-122.

31）白土 (堀越) 東子, 武田直和（2007）2.ノロウイルスと血液型抗 原, ウイルス, 57 (2), 181-190.

32) Bettman, J. R., Payne, J. W. and Staelin, R. (1986) Cognitive Considerations in Designing Effective Labels for Presenting Risk Information, Journal of Public Policy and Marketing, 5, 1-28.

33）安井至, 坂村博康, 伊藤健司, 二宮和之 (2001) CREST研究「社 会的受容性獲得のための情報伝達技術の開発」, 生産研究, 53 (4), 226-230.

34）中山満子 (2007) 電子掲示板に対する態度と情報欲求・親和欲 求との関連, 大阪市立大学学術情報総合センター紀要, 8, 13-18.

\section{[論 文 要 旨 $]$}

本研究では, 飲料水のリスクに関する様々な情報が消費者のリスク認知に対してどのように影響するのか を，提供情報の内容，個人特性，個人属性に着目して評価した。回答者は提供情報の組み合わせにより 11 グループに分けた。情報を提供しなかったグループに比べ, 情報を提供した全てのグループで未知性因子得 点が低くなる効果が見られた一方で, 恐ろしさ因子得点が高くなった。また, 集団感染事例やDALYなど の数值情報によるリスク認知への影響は大きくなかったが, 特に集団感染事例についてはその数值の捉え方 によって人々のリスク認知が異なることが明らかとなった。さらに, 個人特性によるリスク認知への影響と して,「無謀さ」などのリスクに対して能動的かつ積極的に対応する因子が大きいほど，恐ろしさ因子が大 きくなる傾向が見られ，さらにこれらの特性因子得点が高いほど，情報提供の影響を受けやすいことが明ら かとなった。

キーワード : 水道水 ; ボトル水 ; DALY ; 情報提供 ; リスクコミュニケーション 